P-077

原発性肺癌術後に発症した急性間質性肺炎 の 3 症例

NTT東日本関東病院 呼吸器科 · 肺外科

阿部 典文, 小檜山 律

（はじめに）近年，術前に指摘されないような限局性間質 性肺炎合併例に対し手術を行った場合, 術後に特発性間質 性肺炎に進展したり，手術を契機に急性増悪する可能性が 報告されている。 今回, 間質性肺炎非合併例において術後 急性間質性肺炎を発症した 3 症例を経験したので文献的考 察を加え報告する。（症例 1）75歳, 男性. 肺腺癌 I A 期 に対し右上葉切除術, ND2a 施行. 術後細菌性肺炎, 肺瘦 を合併. POD-39に間質性肺炎発症. PSL投与で一時軽快 するも POD-86急性増悪し, POD-129死亡.（症例 2) 75 歳, 男性. 肺扁平上皮癌 I B 期に対し左下葉切除術, ND2a施 行. drain自己抜去による皮下・縦隔気腫の増悪および喘 息発作により呼吸状態悪化し，POD-8から7日間人工呼吸 器管理施行. POD-20 間質性肺炎発症L, POD-57死亡. （症例 3）64歳, 男性. 肺腺癌 I B 期に対し右下葉切除術, ND2a施行．術後順調に経過していたがPOD-9急性間質性 肺炎を発症し, POD-26死亡. (考察) 症例 1, 2 は術前 CT で下葉背側に胸膜直下の僅かな線維化変化を認めるも症例 3では全く認められなかった。術前に今回の様な間質性肺 炎発症を予想することは困難であり，常にその発症を考慮 し，その予防に努めるべきと考える。

P-079

脳動静脈奇形を伴う腫瘤影を呈した肺梗塞 の 1 手術例

国立療養所 南福岡病院 外科

桑原 元尚, 上田 仁, 坂田 敬, 本廣 昭

症例は 51 歳男性, 健康診断で右下肺野の結節影を指摘さ れ当科へ紹介された。胸部 CT では右肺 $\mathrm{S}^{9}$ 胸膜直下に $2 \mathrm{~cm}$ の腫瘤影を認め, 接する部分の壁側胸膜肥厚が指摘された. 頭部 CTで左側頭部後部に低吸収域を指摘されたが転移性 病変とは考えず, 肺悪性疾患を考え胸腔鏡下生検となった。 鏡視下で充血し肥厚した壁側胸膜とそれに接して肺底面か らの胸膜の引き込み，周囲に怒張した血管を伴う腫瘦性病 変を認め, 肺部分切除を行った。割面は白色調で内部に器 質化した血栓を伴う血管が認められた。病理学的診断は肺 梗塞だった。術後血流シンチを行い右肺 $\mathrm{S}^{6} に$ 欠損域を指 摘された。右房内の血栓は無く, 病歴・現症から多発性血 栓症や深部静脈血栓症は否定的だった。左側頭部後部の病 変は脳MRIおよび血管造影でAV shuntを伴う脳梗塞巣で 脳動静脈奇形と診断された. 文献的検討を加えて報告する.
$\mathrm{P}-078$

ゲフィチニブ (イレッサ) によると思われ る間質性肺炎により死亡した肺癌症例一剖 検所見の検討

宇部興产中央病院 外科

\section{工藤 明敏}

(症例) 75 才, 男性. 6 月 19 日右上葉切除術施行. 小細胞 癌 +腺癌. p-T2N2M0 stage 3 A 転移は腺癌. 退院後 9 月 5 日よりゲフィチニブ開始した。10月25日頃より咳が出現 し，11月1日より急に労作時呼吸困難を訴え入院した。 11 月5日 日Tにて両側間質性肺炎を認め, 呼吸困難が増強し, 以後人工呼吸器管理を必要とした. ステロイドパルス投与 (合計 3 回) したが呼吸機能の改善を認めなかった。11月 23 日上部消化管出血したが軽快．12月 12 日大量下血し 12 月13日死亡.（剖検所見）胸膜に近い部分は，線維化と気 管支上皮化した小囊胞状の腔が目立ち, Honeycombパ夕 ーンを呈し, 肺全体の7割以上を占める。間質へは種々の 程度のリンパ球浸潤があり, fibroblast, 膠原線維の増生 が目立つ. 線維化巣の間には比較的intactな肺胞構造もあ るが，呼吸不全の終末像といえる。UIPいわゆる通常型間 質性肺炎として矛盾しないが，organized DADびまん性 肺胞傷害あるいはAIP急性閒質性肺炎の終末像としても 鑑別困難な像である。出血の原因である消化管のびらんは 全身状態を反映したものと考えた。
P_080 肺癌術後急性期に発症した腹部臟器梗塞症

岩手県立中央病院 呼吸器外科

大浦 裕之, 広瀬正秀, 石木 幹人

最近, 肺癌術後の急性期に血栓によると思われる腹部臓器 梗塞をきたした 2 症例を経験したので報告する。【症例 1】 70 歳, 男性. 平成 11 年 6 月, 臨床病期 III Aの肺大細胞癌 の診断にて左下葉切除及びND2aを施行した。術後第 4 病 日に $39{ }^{\circ} \mathrm{C}$ 前後の発熱と腹部の疝痛あり，一時不穏状態と なった。血液検査では白血球増多とLDHの著明な上昇 $(1402 \mathrm{IU} / 1)$ ，さらにBUN，Creの中等度上昇を認めた。腹 部造影CT所見上右腎実質の multiple LDAを認め, 腎シ ンチの結果も併せて腎梗塞の診断となった。 その後, 保存 的に経過観察したが石腎は著明に萎縮した。【症例 2】70 歳，女性。平成 14 年 12 月，臨床病期 I A の肺腺癌の診断 にて左上葉切除及びND2a を施行した。術後第 4 病日に左 上腹部痛あり，同時に吐気，哣吐が出現した。補液等によ る保存療法にても腹部症状が持続し，血液検査ではGOT, GPT 及びLDHの上昇 $(494 \mathrm{IU} / 1)$ を認めた。術後第 9 病日 の腹部造影 CT 所見上, 脾臓に楔状の LDA を認め脾梗塞 と診断した。保存的に経過観察し諸症状は改善した。【結 論】胸部術後に何らかの腹部症状と LDH の著明な上昇を 認めた場合は腹部蔵器梗塞も念頭に置くべきである.また, その確定診断には腹部造影 CT が非常に有用であった。 